\title{
Assessment of Climatic Factors on Growth and Yield of Maize Variety as Influenced by Rates of Sunshine Organic Manure and NPK 20:10:10 Fertilizer
}

\author{
Arije D.N ${ }^{1 *}$; Ewulo B.S ${ }^{1}$; Akinseye, F.M ${ }^{2,3}$; Adejoro, S.A. ${ }^{1}$ \\ ${ }^{1}$ Departments of Crop, Soil and Pest Managements, Federal University of Technology, Akure, Ondo State, Nigeria \\ ${ }^{2}$ Department of Meteorology and Climate Science, Federal University of Technology, Akure, Ondo State, Nigeria \\ ${ }^{3}$ International Crop Research Institute for the Semi-Arid Tropics (ICRISAT), Kano, Nigeria \\ *CorrenspondingAuthor
}

\begin{abstract}
Maize is one of the most important cereal crops in West Africa. Its production in Nigeria has been hindered by inconsistency in rainfall pattern and low fertility especially in Akure, Ondo State. Two experiments were conducted at the Teaching and Research Farm, Federal University of Technology, Akure (FUTA) in 2016 growing season (wet and dry seasons) to determine the effects of Sunshine Organic Manure and NPK 20:10:10 fertilizer on the growth and yield maize variety, as well in soil fertility improvement. The experiment was laid out in a Randomized Complete Block Design (RCBD) with three replications per treatment. Suwan ${ }^{-1}$-SR-Ymaize varietywas used for the experiment and Sunshine Organic manure was applied at the rates of $0,60,90$, and $120 \mathrm{~kg} \mathrm{~N}$ ha ${ }^{-1}$ while NPK 20:10:10 was used as standard at the rate of $70 \mathrm{~kg} \mathrm{~N} \mathrm{ha-1}$. Growth parameters (plant height and number of leaves per plant) were taken at two weeks interval for 12 weeks. At harvest, yield parameters (Seed weight/plant, Weight of 1000 seed $(\mathrm{g})$, Number of seeds/cob, Yield in $t \mathrm{ha}^{-1}$, cob length (cm), cob girth $(\mathrm{cm}))$ were determined. The following weather data were collected; Daily rainfall, maximum \& minimum temperature and solar radiation, while the soil data collected were; $\mathrm{pH}$, total $\mathrm{N}$, available phosphorus, potassium, organic carbon, and bulk density. Statistical Package for Social Sciences (SPSS) was used for the data analyses. Mean separation was done using Duncan's Multiple Range Test (DMRT). Results showed an increase in growth and yield parameters recorded with increasing application rates of Sunshine Organic Manure in both growing season.
\end{abstract}

Keywords-Maize, Fertilizer, climate, Growth, Yield.

\section{INTRODUCTION}

Cereal production is a major component of small-scale farming in West Africa. Among cereals, maize is one of the most important as it forms the major staple food for most communities and contributes about $20 \%$ of calories to human diet (Braimoh and Vlek, 2006). However, average maize yields per unit of land have fallen over the years, partly due to loss in soil fertility as a result of unsustainable farming activities, especially in the wetter areas where the yield potential is higher (Sanchez, 2002) and partly due to low external inputs (Fosuet al., 2004).

As farmers battle with low soil fertility, climate change presents an additional burden, which for them translates into production risks associated with crop yields, due to the probability of extreme events, the uncertainty of the timing of field operations, and of investments in new technologies. The concern for the present and future climate aberrations, weather trends and their implications for agriculture continue to stimulate researchers as well as public and policy-level interests regarding the analysis of climate change in relation to agricultural productivity (IPCC 2007; Cooper et al., 2006). Reported projections indicate that with the trend in climate change and variability, the impacts on people's livelihoods will be greatest in Africa, where many poor smallholders largely or totally rely on rain-fed agriculture and have few alternatives (IPCC, 2001; Bokoet al., 2007), due to high levels of poverty, low levels of human and physical capital, and poor infrastructure (IFPRI, 2009). The specific objective was to determine the effects of organic fertilizer application rates on growth and yield of 
maize as well as assessing the impacts of climate on crop performance.

\section{MATERIALS AND METHODS}

The research experiment was carried out during the rainy season (March - July) and dry season (SeptemberDecember) at the Teaching and Research Farm of the Federal University of Technology, Akure (FUTA) $\left(7^{0} 16^{\prime} \mathrm{N}\right.$, $\left.5^{0} 12^{\prime} \mathrm{E}\right)$ located in the Rain forest agro-ecological zone of Nigeria in 2016 growing season.

Each trial was laid out in a Randomized Complete Block Design (RCBD) with three replications per treatment.The size of the field was $14 \mathrm{~m}$ by $14 \mathrm{~m}\left(196 \mathrm{~m}^{2}\right)$ and each experimental unit was $4 \mathrm{~m}$ by $2 \mathrm{~m}$ with $1 \mathrm{~m}$ alley. There were 15 plots. The allocation of treatments to each experimental unit was done using the Plant Breeding Tools (PBTools) Version: 1.3.

The maize variety (Suwan ${ }^{-1}$-SR-Y) was obtained from the Institute of Agricultural Research and Training, Moor Plantation, Ibadan in Nigeria. It was an improved maize variety fortified with protein. Maize seeds were sown two seeds per hole with a spacing of $75 \mathrm{~cm}$ by $25 \mathrm{~cm}$ but were later thinned to one plant stands 2 weeks after planting. Weeding was carried out manually (hoeing and handpulling). Growth parameters (plant height and number of leaves per plant) were taken at two weeks interval for 12 weeks. At 8 weeks after planting, fresh leaves and stem weights, oven dried leaves and stem weight were determined while the leaf area was determined using the Leaf area meter. Plant height was measured using a tape in centimeters and average leaf number was determined by counting the total number of leaves of two plant stands in each plot. At harvest, yield parameters (Seed weight/plant, Weight of 1000 seed (g), Number of seeds/cob, Yields in $t$ $\mathrm{ha}^{-1}$, Cob length $(\mathrm{cm})$ and Cob girth $(\mathrm{cm})$ ) were determined. The Sunshine Organic Manure (S.O.M) was applied at varying rates of $0,60,90,120 \mathrm{kgN} \mathrm{ha}^{-1}$ and NPK 20:10:10 at $70 \mathrm{kgN} \mathrm{ha}^{-1}$ as recommended rate.

The weather data required include; daily rainfall, maximum \& minimum temperature and solar radiation and were collected from the West African Science Service Center on Climate Change and Adapted Land Use (WASCAL) weather observatory, Federal University of Technology, Akure.

\section{Soil Analysis}

Core samples were used for determination of soil physical properties. The auger samples were air- dried, grinded and passed through $2 \mathrm{~mm}$ sieve and used to determine chemical properties. The methods that were applied were: hydrometer method for soil texture (Jacob and Clark, 2002), Kjeldahl method for total nitrogen (Bremner and Mulvaney, 1982), and the modified Walkley- Black wet oxidation procedure for organic carbon content. Multiplication of the soil organic carbon by 1.72 resulted in soil organic matter (Nelson and Sommers, 1982). Titration method with EDTA solution were used for measuring calcium and magnesium (Lanyon and Heald, 1982), sampling cylinder method for Bulk density (Jacob and Clark, 2002) and the soil pH was carried out using 1:2.5 soil/water ratio and the values were read off using Beckman zeromatric $\mathrm{pH}$ meter (Peech, 1965). The amount of phosphorus in soil extracts of soil were determined by Spectrophotometer (Olsen and Sommers, 1982). Exchangeable $\mathrm{K}$ and $\mathrm{Na}$ after extraction were extracted using $1 \mathrm{~N}$ ammonium acetate $(\mathrm{pH}=7)$ and read with flame photometer (Knudsen et al.,1982). Statistical Package for Social Sciences (SPSS) and Decision Support Systems for Agro-Technology Transfer (DSSAT) were used for data analyses. Mean separation was done using Duncan's Multiple Range Test (DMRT).

\section{RESULTS}

Initial Soil Physicochemical Analysis for both growing seasons

Table 1 shows the monthly means weather data (Rainfall, minimum and maximum temperature and solar radiation) for 2016 at the experimental site. The results of initial chemical and physical analyses of the soil at the experimental site in 2016 for the two growing seasons (wet and dry) are presented in Tables 2 and 3. Both experiments were carried out on the same field. The soil $\mathrm{pH}$ was noted to be slightly acidic across the 3 soil depths $(0-15,15-30$ and $30-45 \mathrm{~cm})$. The soil $\mathrm{pH}$ decrease down the depth $(6.31$, $6.18,6.21)$. The total $\mathrm{N}$ value in the top $15 \mathrm{~cm}$ layer was moderately available during the first growing season, but was low in the second season (0.34 in the first growing season and 0.19 in the second season). The percentage organic matter $(\mathrm{OM})$ was $0.86,0.55$ and 0.43 in top 15,30 and $45 \mathrm{~cm}$ soil layer, respectively. The available phosphorus was low across the 3 layers $0-15\left(10.95 \mathrm{mg} \mathrm{kg}^{-}\right.$ $\left.{ }^{1}\right), 15-30\left(6.54 \mathrm{mg} \mathrm{kg}^{-1}\right)$ and $30-45 \mathrm{~cm}\left(3.43 \mathrm{mg} \mathrm{kg}^{-1}\right)$, exchangeable $\mathrm{K}$ was moderately available at $0-15$ soil depth (0.33) but was low in the top 30 and $45 \mathrm{~cm}$ layer $(0.29$ and $0.24 \mathrm{cmol} \mathrm{kg}^{-1}$, respectively). The textural class of the soil is Sandy clay loam. The soil textural class increased down the soil horizon whiles \% sand decreased with increasing soil depth. The bulk density $\left(\mathrm{g} \mathrm{cm}^{-3}\right)$ in each layer $(0-15,15-30$ and $30-45 \mathrm{~cm}$ ) were $1.52,1.54,1.55$ respectively.

Soil available $\mathrm{P}$ can be rated as low and $\mathrm{K}$ as moderate according to Page et al. (1982). Similarly, the percent 
organic carbon $(0.5$ and 0.55$)$ is rated very low according to Landon (1996).

Effects of Cultivars and Organic Fertilizer Rates on Growth and Yield of Maize in the wet and dry season of 2016

Table 4 shows the effects of fertilizer application on plant height of selected maize varieties during the 2016 wet and dry season. In the wet season, significant differences $(\mathrm{P}>$ 0.05 ) were not observed at 4 and 10 weeks after planting (WAP) while significant differences were recorded in the other weeks. However, maize varieties planted in the control (No fertilizer) plot had the shortest plants across the weeks of the experiments while the plots treated with NPK 20:10:10 had the tallest plants. The sunshine organic manure that was applied at $120 \mathrm{~kg} \mathrm{~N}^{-1}$ performed better compared to the other rates of application (60 and $90 \mathrm{~kg} \mathrm{~N}$ $\left.\mathrm{ha}^{-1}\right)$. Statistically, there was no significant difference $(\mathrm{P}>$ 0.05 ) in the heights of maizetreated with 60,90 and $120 \mathrm{~kg}$ $\mathrm{N} \mathrm{ha}^{-1}$ of Sunshine Organic Manure at 4, 6, 8 and 10WAP. In the dry season planting, significant differences $(P>0.05)$ were observed across the weeks of the experiment (4 12WAP). However, maize varieties planted in the control plot (No fertilizer) had the shortest plant across the other weeks of the experiments while the plot treated with NPK 20:10:10 had the tallest plant. Also from the table, sunshine organic manure that was applied at $120 \mathrm{~kg} \mathrm{~N} \mathrm{ha}^{-1}$ performs better compared to the other rates of application (60 and $90 \mathrm{~kg} \mathrm{~N} \mathrm{ha}{ }^{-1}$ ), although there were no significant differences between plant of maize treated with SOM 90 and $120 \mathrm{~kg} \mathrm{~N}$ $\mathrm{ha}^{-1}$ at 6,10 and 12WAP. Among the Sunshine Organic manure rates, the application at $60 \mathrm{~kg} \mathrm{~N} \mathrm{ha}^{-1}$ had the shortest plant.

The results on the effects of Sunshine Organic manure and NPK fertilizers on number of leaves and leaf area $\left(\mathrm{cm}^{2}\right)$ of selected maize varieties in the wet and dry season of 2016 were presented in (Table 5). In the wet season, significant differences were not recorded in the number of leaves across the weeks of the experiment except at $4 \mathrm{WAP}$ when the control was not significantly different from the others. However, maize treated with NPK 20:10:10 and sunshine organic manure applied at $90 \mathrm{~kg} \mathrm{~N} \mathrm{ha}{ }^{-1}$ had the highest number of leaves. Statistically, no significant differences were observed in the Zea mays number of leaves in all the Organic fertilizer plots across the weeks of the experiment. Regarding the leaf area, there were significant differences (P > 0.05) among the fertilizer rates, the NPK 20:10:10 fertilizer produced maizewith the largest leaf area while the control experiment had the least. Comparing the performance of different organic fertilizer rates, the Sunshine organic manure applied at the rate of $120 \mathrm{~kg} \mathrm{~N}$ ha
${ }^{1}$ had the largest leaf area while SOM applied at $60 \mathrm{~kg} \mathrm{~N}^{2} \mathrm{a}^{-}$ ${ }^{1}$ produced the smallest leaf area

In the dry season experiment, significant differences were recorded in the number of leaf across the weeks of the experiment. However, maize treated with NPK 20:10:10 and sunshine organic manure applied at $120 \mathrm{~kg} \mathrm{~N}^{-1}$ had the highest number of leaf. Statistically, there were no significant differences between the number of leaf of maize treated with SOM at the rate of 90 and $120 \mathrm{~kg} \mathrm{~N} \mathrm{ha}^{-1}$. Regarding the leaf area, there were significant differences ( $P>0.05$ ) among all the fertilizer rates, the NPK 20:10:10 fertilizer produced maize with the largest leaf area while the control experiment had the least. Comparing the performance of different organic fertilizer rates, the Sunshine organic manure applied at the rate of $120 \mathrm{~kg} \mathrm{~N} \mathrm{ha}^{-1}$ had the largest leaf area while SOM applied at $60 \mathrm{~kg} \mathrm{~N} \mathrm{ha}^{-1}$ produced maize with the smallest leaf area. All SOM rates were significantly different from one another.

Table 6 shows the effects of fertilizers on yield parameters (Seed weight/plant, Weight of 1000seed, No of seed/cob, Yield in tha ${ }^{-1}$, Cob length and Cob girth) of selected maize varieties during the wet and dry season of 2016. In the wet season, significant differences were recorded in the across the aforementioned yield parameters. The NPK 20:10:10 produced the highest yield while the control experiment had the least. However, examining the performances of the maize varieties with sunshine organic manures at varying rates of application shows that the SOM $120 \mathrm{~kg} \mathrm{~N} \mathrm{ha}^{-1}$ rate performed best compared to other organic manure rates. Although there was no significant difference among the organic manures rates in the following yield parameters; seed weight/plant and weight of 1000seed. The statistical analysis of the yield parameter also indicated that the control experiment had a better yield because there were no significant differences in the following yield parameters (cob girth, cob length and weight of 1000seed) when compared to the other organic fertilizer rates.

In the second growing season (dry season),significant differences were recorded in the seed weight/plant, Weight of 1000seed, No of seed/cob, Yield in tha ${ }^{-1}$, Cob length and Cob girth. The NPK 20:10:10 fertilizer produced the highest yield while the control experiment had the least. However, regarding the influence of varying Sunshine Organic Manure rate on the maize varieties shows that the SOM applied at the rate of $120 \mathrm{~kg} \mathrm{~N} \mathrm{ha}^{-1}$ performed best compare to other organic manure rates. Although there was no significant difference between the application of SOM at 90 and $120 \mathrm{~kg} \mathrm{~N} \mathrm{ha}^{-1}$ in the following yield parameters; weight of 1000seed, yield in tha ${ }^{-1}$, cob length and cob girth of selected maize varieties. The statistical analysis of the 
yield parameter also indicated that the control experiment was significantly different from the other treatment and also had the lowest yield.

\section{DISCUSSION}

This study clearly demonstrates the effects of Sunshine Organic Manure (SOM) at different rates on the growth and yield of Zea mays. A general assessment of the effects of SOM on growth and yield parameters recorded across the two growing seasons showed that the organic fertilizer positively influenced the performance of the crop with increasing rates of application. However, this trend was clearly observed during the dry season experiment (second growing season) compared to the wet season (first growing season). In the first growing season, the SOM applied at 0, 60,90 and $120 \mathrm{~kg} \mathrm{~N}^{-1}$ were not significantly different from one another for some parameters, such as number of leaves, plant height at 6WAP and 10WAP, weight of 1000seeds, Cob length, Cob girth and seed weight/plant. The control experiment (No fertilizer) had the lowest yield in both trials when compared to the fertilized plots. During the first growing season, significant differences were not observed between the control (no fertilizer) and some application rates of the $\mathrm{SOM}\left(60,90\right.$ and $\left.120 \mathrm{~kg} \mathrm{~N} \mathrm{ha}^{-1}\right)$ for some parameters e.g. plant height at 8WAP, cob length, cob girth and no of seeds/cob. The reason for these results may be attributed to the influence of the existing soil nutrients. From the initial soil analysis, the results revealed that the soil nutrients tested for $\mathrm{N}, \mathrm{P}, \mathrm{K}, \mathrm{Ca}, \mathrm{Ma}, \mathrm{OM}$ and \%OC were moderately available in the soil, according to the soil analysis guidelines for interpretation (Thiagalingam, 2000). This clearly explains the reason why maize normally planted without fertilizer application by local farmers gives a better yield.

It was also observed from the study that NPK proved to be efficacious as a good source of inorganic fertilizer that supported good vegetative growth and yield performance of maize. The NPK 20:10:10 fertilizer performance was better compared to the SOM at different rates $(60,90$ and $120 \mathrm{~kg} \mathrm{~N}$ $\mathrm{ha}^{-1}$ ). However, this may be attributed to the percentage concentrations of Nitrogen, Phosphorus and Potassium present in the SOM (3\% N: $1.5 \%$ P: $1 \% \mathrm{~K})$. The percentage of $\mathrm{N}$ present in the SOM is about 6 times lower as compared to that of $\mathrm{N}$ content of the NPK fertilizer $(20 \% \mathrm{~N})$. The initial soil analysis that was carried out at the commencement of the second experiment revealed that the nitrogen content of the soil was low. The low amount of total soil $\mathrm{N}$ may be attributed to low soil organic matter because Nitrogen is one of the most essential components of organic matter. The decomposition of organic matter leads to the release of some nutrients including $\mathrm{N}$.

The second experiment commenced two weeks after harvesting the first trial. Ploughing was carried out a week after harvesting and a week before planting the second trial. Therefore, the low soil organic matter may be attributed to high C: $\mathrm{N}$ ratio of undecomposed maize residues (straw). A study conducted by Kpongor (2007), stated that crop residues and farmyard manure increases Soil Organic Content.

\section{Effects of environmental factors}

The following environmental factors might have affected the maize performances during the two growing seasons; temperature, moisture availability, solar radiation, soil structure, and soil nutrients.

The first planting commenced on 14 May, 2016; the mean monthly weather data for the Solar Radiation, Maximum Temperature, Minimum Temperature and Rainfall were 18.0, 30.5, 22.9 and 54.8 respectively. Despite the low mean monthly rainfall recorded at the time of establishing the first trial (time of sowing), over $85 \%$ germination was recorded 6 days after sowing (visual observation). This result may be attributed to the influence of the soil physical properties on seed germination. The \% Sand, Silt and Clay of the soil were $60.3 \%, 21.6 \%$ and $18.1 \%$ respectively. The small percentage of clay content present in the soil might have been responsible for soil water retention ability. Also, the bulk density and \% soil moisture content were $1.57 \mathrm{gcm}^{-}$ ${ }^{3}$ and $22.60 \%$ and rainfall was continuous and sufficient.

According to Walter (1967), for sowing it is important to know whether the rains are continuous and sufficient to ensure enough soil moisture during planting, and whether this level will be maintained or even increased during the growing period in order to avoid total crop failure. This is because water is essential for all plant growth and development and it is an integral part of living systems.

However, reduction in maize growth and yield parameters recorded during the $2^{\text {nd }}$ growing season could not be easily linked to soil water availability because the mean average rainfall for both growing season $(197 \mathrm{~mm}$ and $139.3 \mathrm{~mm})$ were enough for optimum yield production. According to Oldeman and Suardi (1977), maize needs an average monthly precipitation of 100 to $140 \mathrm{~mm}$. They basically takes 3 to 3.5 months for optimum growth and will need an average of 300-500 $\mathrm{mm}$ of precipitation during this period. The $2^{\text {nd }}$ growing season began September $1^{\text {st }}, 2016$, and ended December 8th, 2016. Comparing the performances of the maize cultivar in both growing seasons, it was observed that the yield was higher in the first growing season than the second season. Despite the fact that the same treatment 
(Fertilizer types and maize varieties) and management practices were applied, there was a reduction in maize yield. In addition, the experiment was also conducted on the same site (Teaching and Research Farm of the Federal University of Technology, Akure). Also, grains harvested from the first trial were not used as seeds for the second experiment because of the likelihood of segregation, so new similar maize varieties were obtained from the Institute of Agricultural Research and Training, Moor Plantation, Ibadan in Nigeria.

After assessing all the likelihood reasons that may be responsible for low yield recorded during the second experiment, the following factors were suspected to have led to decease in yield of the selected maize cultivars; High temperature and low soil fertility.

$\begin{array}{lllll}\text { Month } & \begin{array}{l}\text { Solar } \\ \text { Radiation }\end{array} & \text { TMax } & \text { TMin } & \text { Rain } \\ \text { September } & 15.7 & 27.5 & 21.7 & 363.2 \\ \text { October } & 18.7 & 29.0 & 21.8 & 168.6 \\ \text { November } & 20.0 & 30.8 & 22.2 & 25.4 \\ \text { December } & 18.7 & 31.4 & 21.4 & 0.0\end{array}$

The table above is an extract from the aforementioned mean monthly weather data for 2016 (January to December). From the table above, it was observed that the solar radiation, Maximum and Minimum Temperature increases from September to December while rainfall decreases. The maize for the second trial was sown on September $1^{\text {st }}, 2016$. The mid-October marked the end of vegetative growth stage and the initiation of the tasseling, silking and milking stage. However, the implication of this on the yield of maize is that increase in temperature will accelerate physiological development i.e. hastening maturation thereby reduces yield. In addition, the soil moisture stress is critical at this development stage (grain filling) of the plant, which can have a serious effect on grain size and weight and hence on yields.

As earlier suggested by Boote and Sinclair (2006) high temperature reduces yield by accelerating physiological development (hastening maturation), not allowing the crop to progress slowly through the season so as to maximize time for the capture of resources and for assimilate partitioning to reproductive structures.

\section{CONCLUSIONS}

Maize grain yield was positively influenced by the rates of the organic fertilizers applied, although the inorganic fertilizer (NPK 20:10:10) had the best yields. The inorganic fertilizer led to decrease in soil $\mathrm{pH}$ while the sunshine organic manure helped maintain the soil $\mathrm{pH}$ within the optimum range. In line with the objective of this study, which was to acquire a better understanding of the yield potentiality of maize variety using the organic fertilizer rates, it shows the efficacious and productivity of the inorganic fertilizer used (NPK 20:10:10) over different organic fertilizer rates (Sunshine Organic Manure at 60, 90 and $120 \mathrm{kgha}^{-1}$ ).

\section{REFERENCES}

[1] Boko, M., Niang, I. A., Nyong, C., Vogel, A., Githeko.M., Medany, B., Osman-Elasha, R. T., and Yanda, P. (2007). Africa. Climate Change 2007: Impacts, Adaptation and Vulnerability. Contribution of Working Group II to the Fourth Assessment Report of the Intergovernmental Panel on Climate Change, M.L. Parry, O.F. Canziani, J.P. Palutikof, P.J. van der Linden and C.E. Hanson, eds., Cambridge University Press, Cambridge UK, 433-467

[2] Boote, K. J. and Sinclair, T. R. (2006). Crop physiology: significant discoveries and our changing perspective on research, Crop Science, Vol. 46, pp. 2270-2277

[3] Braimoh, A. K. and Vlek, P. (2006). Soil quality and other factors influencing maize yield in northern Ghana. Soil Use and Management. 22: 165-171

[4] Bremmer, J. M. and Mulvancy, C.S. (1982).Nitrogen, total organic carbon. In: page et al. (1982). Method of soil Analysis. Part II. American Society Agronomy, Wisconsin, Madison, 595-624.

[5] Cooper, P., Dimes, J., Rao, K., Shapiro, B., Shiferaw, B. and Twomlow, S. (2006). Coping better with current climatic variability in the rain-fed farming systems of sub-saharan Africa: A dress rehearsal for adopting to future climate change? Global theme on Agroecosystems report no 27. pp 1-19

[6] Fosu, M., Ronald, F. K.andVlek, P. (2004). Improving maize yield in the Guinea savannah zone of Ghana with leguminous cover crops and PK fertilization. Journal of Agronomy 3 (2): 115-121

[7] Intergovernmental Penal on Climate Change (IPCC) (2001).The scientific Basis.Working group 1 Contribution to the IPCC Third Assessment Report. Online at http://www.ipcc.ch, November 2001

[8] IPCC (2007).Fourth Assessment Report. Working Group II. Impacts, adaptation and Vulnerability on Agriculture. 
[9] International Food Policy Research Institute (IFPRI) (2009).“Climate Change Impact on Agriculture and Cost of Adaptation".Food Policy Report. Washington D.C

[10]Jacob, H., and Clarke, G., 2002, Methods of Soil Analysis, Part 4, Physical Method, Soil Science Society of America, Inc, Madison, Wisconsin, USA, $1692 \mathrm{p}$

[11] Kpongor, D. S., (2007).Spatially explicit modeling of sorghum (Sorghum bicolor (L.)Moench) production on complex terrain of a semi-arid region in Ghana using APSIM.Ecology and Development Series No 51.PhD Dissertation.pp 78 -104

[12] Lanyon, L. E., and Heald, W.R., (1982).Magnesium, calcium,strontium and barium. In: Methods of soil analysis. Part $22^{\text {nd }}$ ed. Page AL, Miller RH, Keeney DR (Eds). Agronomy No. 9 American Society of Agronomy, Madison WI, pp. 247-262
[13] Nelson, D. W., and Sommers, L. E., (1982), Total carbon and organic matter.In Methods of soil analysis, part 2, ed. A. L. Page. Madison, Wisc.: ASA-SSSA

[14] Oldeman, L. R.and Suardi, D. (1977). Climatic determinants in relation to cropping patterns. In IRRI proceedings symposium on cropping systems research and development for the Asian farmer. 21 to 24 September 1976. I RRI, Los Banos, Philippines

[15] Peech, M. (1965).Hydrogen ion activity. In: Black, C. A. (ed) Methods of soil Analysis part 2. American Societyof Agronomy. 9:914-926.

[16] Sanchez, P. E. (2002). Soil Fertility and Hunger in Africa. Science, 295: 2019-2020

[17] Walter, M. (1967).Length of the rainy season in Nigeria. Nigerian Geographical Journal of Agricultural Science 10, 123-128

[18] Walter, M. (1967).Length of the rainy season in Nigeria. Nigerian Geographical Journal of Agricultural Science 10, 123-128

\section{TABLES}

Table.1: Monthly Means Weather data for 2016 at the experimental site

\begin{tabular}{lcccc}
\hline Month & $\begin{array}{c}\text { Solar Radiation } \\
\left(\mathrm{W} / \mathrm{m}^{2}\right)\end{array}$ & Maximum Air Temperature $\left({ }^{\circ} \mathrm{C}\right)$ & $\begin{array}{c}\text { Minimum Air Temperature } \\
\left({ }^{\circ} \mathrm{C}\right)\end{array}$ & $\begin{array}{c}\text { Rainfall } \\
(\mathrm{mm})\end{array}$ \\
\hline January & 18.8 & 33.8 & 19.6 & 9.4 \\
February & 19.0 & 35.4 & 22.0 & 0.0 \\
March & 17.1 & 33.1 & 24.0 & 149.8 \\
April & 19.4 & 32.1 & 23.7 & 15.6 \\
May & 18.0 & 30.5 & 22.9 & 54.8 \\
June & 15.6 & 28.2 & 21.9 & 321.6 \\
July & 14.4 & 27.4 & 21.6 & 148.4 \\
August & 13.5 & 27.4 & 21.4 & 263.2 \\
September & 15.7 & 27.5 & 21.7 & 363.2 \\
October & 18.7 & 29.0 & 21.8 & 168.6 \\
November & 20.0 & 30.8 & 22.2 & 25.4 \\
December & 18.7 & 31.4 & 21.4 & 0.0 \\
\hline
\end{tabular}

Source:West African Science Service Center on Climate Change and Adapted Land Use (WASCAL) weather station

Table.2: Initial Soil Physicochemical Analysis for the first growing season

\begin{tabular}{lccc}
\hline & $\mathbf{0 - 1 5}$ & $\begin{array}{c}\mathbf{1 5 - 3 0} \\
\text { Depth (bottom), cm }\end{array}$ & $\mathbf{3 0 - 4 5}$ \\
\hline Particle size analysis (\%) & & & \\
Clay & 21.6 & 22 & 26.5 \\
Silt & 18.1 & 18.6 & 18.9 \\
Sand & 60.3 & 59.4 & 54.6 \\
& & & \\
Bulk density g/cm & & 1.54 & 1.55 \\
Soil pH & 1.52 & 6.18 & 6.21 \\
Nitrogen (\%) & 6.31 & 0.31 & 0.29 \\
Phosphorus (mg kg-1) & 0.34 & 6.54 & 3.43 \\
\hline
\end{tabular}


Organic Matter

Exchangeable cation $\left(\mathrm{cmol} \mathrm{kg}^{-1}\right)$

Potassium

Calcium

Magnesium

ECEC

\subsection{6}

0.33

3.10

2.00

17.86
0.55

0.29

4.01

1.80

19.41

Table.3: Initial Soil Physicochemical Analysis for the second growing season

\begin{tabular}{|c|c|c|c|}
\hline & $0-15$ & 15-30 & $30-45$ \\
\hline & \multicolumn{3}{|c|}{ Depth (bottom), cm } \\
\hline \multicolumn{4}{|c|}{ Particle size analysis (\%) } \\
\hline Clay & 22.0 & 23.1 & 28.2 \\
\hline Silt & 19.7 & 21.5 & 19.5 \\
\hline Sand & 58.3 & 55.4 & 52.3 \\
\hline Bulk density $\mathrm{g} / \mathrm{cm}^{3}$ & 1.53 & 1.51 & 1.52 \\
\hline Soil pH & 6.22 & 6.17 & 6.19 \\
\hline Nitrogen $(\%)$ & 0.19 & 0.16 & 0.15 \\
\hline Phosphorus (mg/kg) & 6.92 & 4.45 & 3.21 \\
\hline Organic Matter & 0.95 & 0.86 & 0.73 \\
\hline \multicolumn{4}{|c|}{$\underline{\text { Exchangeable cation }\left(\mathrm{cmol}^{\mathrm{kg}}{ }^{-1}\right)}$} \\
\hline Potassium (cmol/kg) & 0.25 & 0.23 & 0.20 \\
\hline Calcium (cmol/kg) & 2.73 & 3.23 & 3.13 \\
\hline Magnesium (cmol/kg) & 1.17 & 1.15 & 1.14 \\
\hline ECEC & 20.12 & 17.54 & 15.26 \\
\hline
\end{tabular}

Table.4: Effects of fertilizer treatments on plant height of maize at successive growth periods in the wet and dry season of 2016

\begin{tabular}{ccccc}
\hline Fertilizer & \multicolumn{3}{c}{ Weeks after planting } \\
Treatment (Kg N/ha) & 4 & 6 & 8 & 10 \\
\hline 0 & $49.30 \mathrm{a}$ & Wet season & $190.89 \mathrm{a}$ \\
SOM 60 & $51.74 \mathrm{a}$ & $84.87 \mathrm{a}$ & $144.07 \mathrm{a}$ & $198.89 \mathrm{a}$ \\
SOM 90 & $54.60 \mathrm{a}$ & $91.88 \mathrm{ab}$ & $144.67 \mathrm{a}$ & $204.11 \mathrm{a}$ \\
SOM 120 & $57.62 \mathrm{a}$ & $91.07 \mathrm{ab}$ & $155.29 \mathrm{a}$ & $213.67 \mathrm{a}$ \\
NPK 70 & $58.61 \mathrm{a}$ & $96.20 \mathrm{ab}$ & $158.71 \mathrm{ab}$ & $218.33 \mathrm{a}$ \\
0 & & $115.06 \mathrm{~b}$ & $184.96 \mathrm{~b}$ & $135.53 \mathrm{a}$ \\
SOM 60 & $42.44 \mathrm{a}$ & Dry season & & $158.36 \mathrm{~b}$ \\
SOM 90 & $46.64 \mathrm{ab}$ & $59.25 \mathrm{a}$ & $95.38 \mathrm{a}$ & $163.44 \mathrm{~b}$ \\
SOM 120 & $50.98 \mathrm{~b}$ & $71.11 \mathrm{~b}$ & $108.07 \mathrm{ab}$ & $167.64 \mathrm{~b}$ \\
NPK 70 & $60.50 \mathrm{c}$ & $83.38 \mathrm{c}$ & $114.67 \mathrm{ab}$ & $191.47 \mathrm{c}$
\end{tabular}


Means in the same columns not followed by same letters are significantly different at 5\% level of probability by Duncan's Multiple Range Test (DMRT).

Table.5: Effects of fertilizer treatments on number of leaves and leaf area of Maizeat successive growth periods in the wet and dry season of 2016

\begin{tabular}{|c|c|c|c|c|c|}
\hline \multirow{2}{*}{$\begin{array}{l}\text { Fertilizer } \\
\text { Treatment (Kg N/ha) }\end{array}$} & \multicolumn{4}{|c|}{ Weeks after planting } & \multirow{2}{*}{$\begin{array}{l}\text { Leaf Area at 8WA } \\
\qquad\left(\mathrm{cm}^{2}\right)\end{array}$} \\
\hline & 4 & 6 & 8 & 10 & \\
\hline \multicolumn{6}{|c|}{ Wet season } \\
\hline 0 & $7.57 \mathrm{ab}$ & $10.09 a$ & $10.90 \mathrm{a}$ & $9.44 \mathrm{a}$ & $754.22 \mathrm{a}$ \\
\hline SOM 60 & $6.66 \mathrm{a}$ & $9.97 \mathrm{a}$ & $10.73 a$ & $9.44 \mathrm{a}$ & $867.43 \mathrm{ab}$ \\
\hline SOM 90 & $8.12 b$ & $10.59 a$ & $10.92 \mathrm{a}$ & $10.06 \mathrm{a}$ & $979.37 \mathrm{bc}$ \\
\hline SOM 120 & $8.02 b$ & $10.38 \mathrm{a}$ & $11.43 \mathrm{a}$ & $9.50 \mathrm{a}$ & $1025.74 \mathrm{~cd}$ \\
\hline NPK 70 & $8.40 \mathrm{~b}$ & $10.83 a$ & $11.41 \mathrm{a}$ & $10.28 \mathrm{a}$ & $1133.12 d$ \\
\hline \multicolumn{6}{|c|}{ Dry season } \\
\hline 0 & $6.70 \mathrm{a}$ & $6.40 \mathrm{a}$ & 7.91a & $8.93 \mathrm{a}$ & $747.72 \mathrm{a}$ \\
\hline SOM 60 & 7.43ab & 7.49ab & $8.91 \mathrm{ab}$ & $9.58 \mathrm{ab}$ & $860.93 \mathrm{ab}$ \\
\hline SOM 90 & $7.83 \mathrm{bc}$ & $8.51 b c$ & $9.71 b c$ & $10.04 b c$ & $972.87 \mathrm{bc}$ \\
\hline SOM 120 & $8.40 \mathrm{bc}$ & $9.31 b c$ & $10.42 b c$ & $10.56 \mathrm{bc}$ & $1019.24 \mathrm{~cd}$ \\
\hline NPK 70 & $9.33 c$ & $10.27 \mathrm{c}$ & $11.04 \mathrm{c}$ & $11.33 \mathrm{c}$ & $1126.62 d$ \\
\hline
\end{tabular}

Means in the same columns not followed by same letters are significantly different at 5\% level of probability by Duncan's Multiple Range Test (DMRT).

Table.6: Effects of fertilizers on yield parameters of selected maize varietiesduring the wet and dry season of 2016

\begin{tabular}{|c|c|c|c|c|c|c|}
\hline $\begin{array}{l}\text { Fertilizer Treatment } \\
(\mathrm{Kg} \mathrm{N} / \mathrm{ha})\end{array}$ & $\begin{array}{c}\text { Seed } \\
\text { weight/plant }\end{array}$ & $\begin{array}{c}\text { Weight of } \\
1000 \text { seed }(\mathrm{g})\end{array}$ & No of seed/cob & Yield in $\mathrm{T} \mathrm{ha}^{-1}$ & $\begin{array}{l}\text { Cob length } \\
(\mathrm{cm})\end{array}$ & $\begin{array}{l}\text { Cob girth } \\
(\mathrm{cm})\end{array}$ \\
\hline \multicolumn{7}{|c|}{ Wet season } \\
\hline 0 & $171.67 \mathrm{a}$ & $333.33 \mathrm{a}$ & $273.56 a$ & $1147.67 \mathrm{a}$ & $12.79 a$ & $8.28 \mathrm{a}$ \\
\hline SOM 60 & $203.78 \mathrm{ab}$ & $345.56 \mathrm{a}$ & $328.39 \mathrm{ab}$ & $1265.78 \mathrm{ab}$ & $15.36 \mathrm{ab}$ & $9.96 \mathrm{ab}$ \\
\hline SOM 90 & $215.01 \mathrm{ab}$ & $365.56 \mathrm{a}$ & $322.94 a$ & $1392.00 \mathrm{ab}$ & $15.08 \mathrm{a}$ & $9.79 a$ \\
\hline SOM 120 & $229.00 \mathrm{ab}$ & $360.00 \mathrm{a}$ & $347.61 \mathrm{ab}$ & $1511.56 \mathrm{~b}$ & $16.22 \mathrm{ab}$ & $10.53 \mathrm{ab}$ \\
\hline \multicolumn{7}{|c|}{ Dry season } \\
\hline 0 & $89.67 \mathrm{a}$ & $237.78 \mathrm{a}$ & $206.00 \mathrm{a}$ & $569.44 \mathrm{a}$ & $9.78 \mathrm{a}$ & $6.34 \mathrm{a}$ \\
\hline SOM 60 & $131.22 b$ & $277.78 b$ & $302.33 b c$ & $820.56 b$ & $14.06 \mathrm{ab}$ & $9.10 \mathrm{ab}$ \\
\hline NPK 70 & $256.22 \mathrm{e}$ & $363.33 d$ & $458.44 d$ & $1619.44 d$ & $21.16 \mathrm{c}$ & $13.73 \mathrm{c}$ \\
\hline
\end{tabular}

Means in the same columns not followed by same letters are significantly different at 5\% level of probability by Duncan's Multiple Range Test (DMRT). 